\title{
Biology and Life Table Parameters of Tetranychus urticae Koch (Acari: Tetranychidae) and Two Phytoseiid Predatory Mites on Two Watermelon Cultivars
}

\author{
F. S. Ali"; A. M. Afifi ${ }^{*}$; E.M.A.El-Saiedy ${ }^{* *}$ and M. M. Ahmed ${ }^{*}$ \\ "Zoology and Agric. Nematology Dept., Faculty of Agriculture, Cairo Univ., Giza, Egypt \\ "Plant Protection Dept., National Research Center, 12622 Dokki, Cairo, Egypt
}

\begin{abstract}
The duration of developmental stages and life table parameters of the two spotted-spider mite; Tetranychus urticae Koch and the two predatory mites; Phytoseiulis persimilis Athias-Henriot and Neoseiulis californicus McGregor were carried out at the laboratory (on two different temperatures; $25 \pm 1^{\circ} \mathrm{C}$ and $30 \pm 1^{\circ} \mathrm{C}$ and (R.H.) $70 \%$ ) on leaves of two watermelon cultivars; Aswan and Giza-1, which had a high and low infestation, respectively with T. urticae. The two watermelon cultivars and the two temperature degrees affected the duration of all developmental stages as well as adult longevity and female fecundity of T. urticae, P. persimilis and N. californicus. Duration of female developmental stages being the shortest when rearing on leaves of Aswan cultivar at $30^{\circ} \mathrm{C}$ and the longest on leaves of Giza-1 cultivar at $25^{\circ} \mathrm{C}$. The shortest mean generation time (T) of T. urticae was 13.68 days on Aswan cultivar at $30^{\circ} \mathrm{C}$; while the longest was 19.52 days on Giza- 1 cultivar at $25^{\circ} \mathrm{C}$. The highest net reproductive rate $\left(\mathrm{R}_{\mathrm{o}}\right)$ and intrinsic rate of natural increase $\left(\mathrm{r}_{\mathrm{m}}\right)$ were 32.81 \% $/ 9 \& 0.255 \% / q /$ day on Aswan cultivar at $30^{\circ} \mathrm{C}$, respectively and the lowest were 15.04 웅 \& 0.139 \% / $/$ /day on Giza- 1 cultivar at $25^{\circ} \mathrm{C}$, respectively. The shortest $(\mathrm{T})$ of $P$. persimilis was 12.40 days on Aswan cultivar at $30^{\circ} \mathrm{c}$, and the longest was 16.41 days on Giza- 1 cultivar at $25^{\circ} \mathrm{c}$. The highest $\left(\mathrm{r}_{\mathrm{m}}\right)$ was 0.285 O $/$ \% / day on Aswan cultivar at $30^{\circ} \mathrm{c}$; while the lowest was 0.217 우우 /day on Giza-1 cultivar at $25^{\circ} \mathrm{C} . N$. californicus showed similar trend as that of $P$. persimilis but with lower values in $\left(\mathrm{R}_{\mathrm{o}}\right)$ and $\left(\mathrm{r}_{\mathrm{m}}\right)$.
\end{abstract}

Key Words: Biology, Life table parameters, Phytoseiulus persimilis, Neoseiulus californicus, Tetranychus urticae. Watermelon cultivar.

\section{INTRODUCTION}

Knowledge of population growth potential is crucial for studying population dynamics and for establishing management tactics for pest control. Estimation of population growth can be achieved with fertility life tables because they synthesize data on reproduction and mortality of a population.

Bengston (1970) reported that apple cultivars had a significant effect on both developmental times and reproductive potential of $T$. urticae. Vrie et al. (1972) stated that the different plant species or varieties affected the increase potentials for tetranychid mites, and these differences might be associated with the nutriment produced by plant. Additionally, Crooker (1985) indicated that the chemical constitution of the leaf might influence fecundity, mortality and development of the immature stages of spider mites, especially the host plant nitrogen content. Tomczyk \& Kropczynska (1986) reported that the feeding time and population density of spider mites depend on the length of their stylets and host plant leaf characteristics. ElSeidy et al., 2011 estimated the susceptibility of four watermelon cultivars to infestation with $T$. urticae and its population fluctuation during two successive seasons and found differentiation in its susceptibility.

The net reproductive rate $\left(R_{o}\right)$ and the intrinsic rate of increase $\left(\mathrm{r}_{\mathrm{m}}\right)$ are important indicators of tetranychid population dynamics (Laing, 1969 and Sabelis, 1985). Comparisons of $R_{o}$ and $r_{m}$ often provide considerable insight beyond that available from the independent analysis of individual life history parameters (Zhang et al., 2007).

The objective of this study is investigate the effect of watermelon cultivars and temperature on the biology and life table parameters of T. urticae, Phytoseiulus persimilis (A.-H.) and Neoseiulis californicus (McGregor).

\section{MATERIALS AND METHODS}

The duration of developmental stages, life history, female fecundity of the spider mite $T$. urticae and the two predatory mites; Phytoseiulis persimilis Athias-Henriot and Neoseiulis californicus McGregor were carried out on leaves of the two watermelon cultivars Aswan and Giza-1 which had high and low infestation with $T$. urticae at $25 \pm 1^{\circ} \mathrm{C}, 30 \pm 1^{\circ} \mathrm{C}$ and $70 \%$ R.H.

Watermelon leaf discs $(2 \mathrm{~cm}$ diameter $)$ were placed on cotton bed in Phil dish $(20 \mathrm{~cm} \times 15 \mathrm{~cm})$ with under surface upward. The cotton bed was soaked with water twice daily. Ten $T$. urticae adult females collected from the laboratory stock cultures were transferred to each disc for laying eggs. For solitary rearing, newly deposited eggs of the same 
age were transferred singly, each to a leaf disc. Every dish contained 30 discs.

Dishes with discs were kept at $25 \pm 1^{\circ} \mathrm{C}, 30 \pm 1^{\circ} \mathrm{C}$ and $70 \%$ R.H. Discs were examined twice daily and all biological aspects were recorded until death of mite individuals.

The same method techniques were used for the biology of $P$. persimilis and $N$. californicus. $T$. urticae immatures were used as prey.

Life tables of $T$. urticae, $P$. persimilis and $N$. californicus at the two different temperatures were constructed from the life history and fecundity data. The actual death occurred in the egg and immature stages were taken into account when the female survival rate at each temperature was determined. Life tables were constructed using the survival data of a specific age class $(\mathrm{L} \mathrm{x})$ and the female offspring produced per female in each age class $(\mathrm{mx})$. The net reproductive rate $\left(R_{o}\right)$, the mean generation time $(T)$, the intrinsic rate of increase $\left(r_{m}\right)$, and the finite rate of increase $(\lambda)$ were calculated according to (Birch, 1948) using the basic computer program of (Abou-Setta et al., 1986).

\section{RESULTS AND DISCUSSION}

a. Duration of developmental stages of Tetranychus urticae, reared on leaves of two watermelon cultivars at two different temperatures

Two different watermelon cultivars and two temperature degrees affected the duration of every developmental stage as well as adult longevity and female fecundity of $T$. urticae, Tables (1\&2). Female life cycle duration and adult span differed according to the two different watermelon cultivars and temperatures, being the shortest on leaves of Aswan cultivar at $30^{\circ} \mathrm{C}$ and the longest on leaves of Giza-1 cultivar at $25^{\circ} \mathrm{C}$. Male showed similar trend but with slightly shorter periods.

b. Duration of developmental stages of $P$. persimilis and $N$. californicus fed on $T$. urticae infesting leaves of the two watermelon cultivars and at two different temperatures

The shortest egg incubation, total immatures, life cycle, adult longevity and life span of $P$. persimilis female were the smallest on Aswan cultivar at $30^{\circ} \mathrm{C}$; while the longest were on Giza- 1 cultivar at $25^{\circ} \mathrm{C}$ (Tables 1\&2). N. californicus followed similar trend as averaged 2.03, 3.66, 5.59, 23.09 and 28.78 days on Aswan cultivar at $30^{\circ} \mathrm{C}$, and $2.63,5.04,7.67$, 32.53 and 40.20 days on Giza-1 cultivar at $25^{\circ} \mathrm{C}$, respectively. Male showed similar trend as female but with slightly shorter periods (Tables $1 \& 2$ ).

c- Effect of two watermelon cultivars on longevity and fecundity of $T$. urticae, $P$. persimilis and $N$. californicus female at two different temperatures

The number of deposited eggs per female and daily rate of $T$. urticae averaged $49.2 \& 9.32 ; 30.39 \&$ 6.80 eggs when reared on leaves of Aswan and Giza-1cultivars at $30^{\circ} \mathrm{C}$, respectively, but at $25^{\circ} \mathrm{C}$ it averaged $50.67 \& 7.07$ and $26.24 \& 4.94$ eggs, respectively.

Daily egg production of $T$. urticae reached its peak on the $5^{\text {th }}$ day on Aswan cultivar at $30^{\circ} \mathrm{C}(7.74$ eggs/P/day), on $4^{\text {th }} \& 5^{\text {th }}$ day on Aswan cultivar at $25^{\circ} \mathrm{C}$ (5.68 eggs/\%/day), on $3^{\text {rd }}$ day on Giza-1 cultivar at $30^{\circ} \mathrm{C}(5.24 \mathrm{eggs} / 9 /$ day $)$, and $4^{\text {th }}$ day on Giza-1 cultivar at $25^{\circ} \mathrm{C}$ (4.21 eggs/Q/day); egg production decreased gradually thereafter. In general, there as no distinct $\mathrm{m}_{\mathrm{x}}$ peak, egg production was distributed over a relatively long time period on two tested cultivars, and survival declined gradually after an extended oviposition period (Fig.1).

The total fecundity and egg number laid per day of $P$. persimilis averaged $46.43 \& 2.88$ and $45.38 \& 2.63$ eggs on Aswan and Giza-1cultivars at $30^{\circ} \mathrm{C}$, respectively, but at $25{ }^{\circ} \mathrm{C}$ it averaged $51.52 \& 2.66$; and $55.53 \& 2.63$ eggs, respectively. Daily egg production of $P$. persimilis reached its peak on day 9 and day 10 on Aswan and Giza-1 cultivars (2.64 \& $2.47 \mathrm{eggs} / \mathrm{P} /$ day $)$ at $30^{\circ} \mathrm{C}$, respectively, but at $25^{\circ} \mathrm{C}$ it was on day 14 and day 4 on Aswan and Giza-1 cultivars (2.63 \& $2.27 \mathrm{eggs} /$ $/$ day), respectively.

The highest egg number laid per day per N. californicus female averaged 1.92 eggs on Aswan cultivar at $25^{\circ} \mathrm{C}$, while the lowest was 1.40 eggs on Giza-1 cultivar at $30^{\circ} \mathrm{C}$. The total fecundity per female shown in Table 3 and Fig. 3.

\section{d- Effect of two watermelon cultivars on the life table parameters of $T$. urticae, $P$. persimilis and $N$. californicus female at two different temperatures}

The shortest mean generation time (T) of T. urticae was 13.68 days on Aswan cultivar at $30^{\circ} \mathrm{C}$; while the longest was 19.52 days on Giza- 1 cultivar at $25^{\circ} \mathrm{C}$. Its highest net reproductive rate $\left(\mathrm{R}_{\mathrm{o}}\right)$ was 32.81 female/female on Aswan cultivar at $30^{\circ} \mathrm{C}$, and the lowest was 15.04 female/female on Giza-1 cultivar at $25^{\circ} \mathrm{C}$. 
Table 1. Duration of developmental stages of Tetranychus urticae, Phytoseiulus persimilis and Neoseiulus californicus on leaves of two watermelon cultivars at $25 \pm 1^{\circ} \mathrm{C}$

\begin{tabular}{|c|c|c|c|c|c|c|c|}
\hline \multirow{3}{*}{ Stages } & \multirow{3}{*}{ Sex } & \multicolumn{6}{|c|}{ Duration in days of two watermelon cultivars at $25 \pm 1^{\circ} \mathrm{C}$} \\
\hline & & \multicolumn{3}{|c|}{ Aswan } & \multicolumn{3}{|c|}{ Giza-1 } \\
\hline & & T. urticae & P. persimilis & N. californicus & T. urticae & P. persimilis & N. californicus \\
\hline \multirow{2}{*}{ Egg } & $\hat{0}$ & $4.21 \pm 0.18$ & $1.90 \pm 0.19$ & $2.30 \pm 0.34$ & $4.20 \pm 0.20$ & $2.29 \pm 0.15$ & $2.60 \pm 0.19$ \\
\hline & q & $4.36 \pm 0.11$ & $2.05 \pm 0.08$ & $2.38 \pm 0.08$ & $4.56 \pm 0.10$ & $2.34 \pm 0.12$ & $2.63 \pm 0.10$ \\
\hline \multirow{2}{*}{ Larva } & $\hat{0}$ & $2.57 \pm 0.23$ & $1.10 \pm 0.10$ & $0.90 \pm 0.19$ & $4.00 \pm 0.22$ & $1.43 \pm 0.17$ & $1.30 \pm 0.12$ \\
\hline & q & $3.11 \pm 0.14$ & $1.33 \pm 0.08$ & $1.06 \pm 0.11$ & $4.03 \pm 0.12$ & $1.42 \pm 0.11$ & $1.41 \pm 0.08$ \\
\hline \multirow{2}{*}{ Protonymph } & $\hat{0}$ & $2.57 \pm 0.20$ & $1.30 \pm 0.12$ & $1.60 \pm 0.29$ & $3.50 \pm 0.60$ & $1.50 \pm 0.19$ & $1.70 \pm 0.12$ \\
\hline & q & $2.86 \pm 0.12$ & $1.31 \pm 0.06$ & $1.74 \pm 0.08$ & $3.44 \pm 0.10$ & $1.74 \pm 0.12$ & $1.97 \pm 0.10$ \\
\hline \multirow{2}{*}{ Deutonymph } & $\hat{\sigma}$ & $2.79 \pm 0.10$ & $1.60 \pm 0.19$ & $1.10 \pm 0.10$ & $3.30 \pm 0.12$ & $1.93 \pm 0.13$ & $1.40 \pm 0.19$ \\
\hline & q & $2.92 \pm 0.12$ & $1.74 \pm 0.07$ & $1.47 \pm 0.11$ & $3.50 \pm 0.09$ & $2.03 \pm 0.10$ & $1.66 \pm 0.11$ \\
\hline \multirow{2}{*}{$\begin{array}{l}\text { Total } \\
\text { immatures }\end{array}$} & $\hat{0}$ & $7.93 \pm 0.37$ & $4.00 \pm 0.22$ & $3.60 \pm 0.29$ & $10.80 \pm 0.46$ & $4.86 \pm 0.18$ & $4.40 \pm 0.19$ \\
\hline & $q$ & $8.89 \pm 0.24$ & $4.38 \pm 0.10$ & $4.27 \pm 0.19$ & $10.97 \pm 0.16$ & $5.19 \pm 0.15$ & $5.04 \pm 0.18$ \\
\hline \multirow{2}{*}{ Life cycle } & 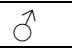 & $12.14 \pm 0.45$ & $5.90 \pm 0.29$ & $5.90 \pm 0.48$ & $15.00 \pm 0.42$ & $7.15 \pm 0.26$ & $7.00 \pm 0.32$ \\
\hline & q & $13.25 \pm 0.23$ & $6.43 \pm 0.13$ & $6.65 \pm 0.23$ & $15.53 \pm 0.16$ & $7.53 \pm 0.16$ & $7.67 \pm 0.23$ \\
\hline \multirow{2}{*}{$\begin{array}{l}\text { Adult } \\
\text { longevity }\end{array}$} & $0^{\pi}$ & $6.79 \pm 0.24$ & $17.80 \pm 1.39$ & $20.80 \pm 2.44$ & $5.50 \pm 0.27$ & $18.14 \pm 0.91$ & $24.00 \pm 1.26$ \\
\hline & $q$ & $11.44 \pm 0.36$ & $27.67 \pm 0.92$ & $29.94 \pm 1.05$ & $9.82 \pm 0.30$ & $29.82 \pm 0.69$ & $32.53 \pm 0.96$ \\
\hline \multirow{2}{*}{ Life span } & $\hat{0}$ & $18.93 \pm 0.53$ & $23.70 \pm 1.66$ & $26.70 \pm 2.27$ & $20.50 \pm 0.65$ & $25.29 \pm 0.98$ & $31.00 \pm 1.26$ \\
\hline & $q$ & $24.69 \pm 0.32$ & $34.10 \pm 0.90$ & $36.59 \pm 1.12$ & $25.35 \pm 0.33$ & $37.35 \pm 0.72$ & $40.20 \pm 1.05$ \\
\hline
\end{tabular}

Table (2). Duration of developmental stages of Tetranychus urticae, Phytoseiulus persimilis and Neoseiulus californicus on leaves of two watermelon cultivars at $30 \pm 1^{\circ} \mathrm{C}$

\begin{tabular}{|c|c|c|c|c|c|c|c|}
\hline \multirow{3}{*}{ Stages } & \multirow{3}{*}{ Sex } & \multicolumn{6}{|c|}{ Duration in days of two watermelon cultivars at $30 \pm 1^{\circ} \mathrm{C}$} \\
\hline & & \multicolumn{3}{|c|}{ Aswan } & \multicolumn{3}{|c|}{ Giza-1 } \\
\hline & & T. urticae & P. persimilis & N. californicus & T. urticae & P. persimilis & N. californicus \\
\hline \multirow{2}{*}{ Egg } & $\hat{0}$ & $3.33 \pm 0.21$ & $1.80 \pm 0.20$ & $2.13 \pm 0.24$ & $3.57 \pm 0.17$ & $1.63 \pm 0.13$ & $2.00 \pm 0.29$ \\
\hline & $q$ & $3.43 \pm 0.13$ & $1.85 \pm 0.07$ & $2.03 \pm 0.08$ & $3.83 \pm 0.09$ & $2.10 \pm 0.10$ & $2.21 \pm 0.11$ \\
\hline \multirow{2}{*}{ Larva } & $\hat{0}$ & $1.92 \pm 0.24$ & $0.70 \pm 0.12$ & $1.00 \pm 0.20$ & $2.50 \pm 0.19$ & $1.00 \pm 0.20$ & $1.17 \pm 0.17$ \\
\hline & q & $2.12 \pm 0.10$ & $0.89 \pm 0.09$ & $0.97 \pm 0.09$ & $2.53 \pm 0.09$ & $1.04 \pm 0.05$ & $1.21 \pm 0.10$ \\
\hline \multirow{2}{*}{ Protonymph } & 1 & $2.25 \pm 0.11$ & $1.20 \pm 0.12$ & $1.25 \pm 0.14$ & $2.79 \pm 0.21$ & $1.13 \pm 0.13$ & $1.67 \pm 0.17$ \\
\hline & q & $2.45 \pm 0.11$ & $1.20 \pm 0.11$ & $1.58 \pm 0.08$ & $2.78 \pm 0.12$ & $1.08 \pm 0.09$ & $1.68 \pm 0.10$ \\
\hline \multirow{2}{*}{ Deutonymph } & $\hat{\sigma}$ & $2.08 \pm 0.15$ & $1.20 \pm 0.12$ & $1.13 \pm 0.13$ & $2.43 \pm 0.17$ & $1.38 \pm 0.24$ & $1.17 \pm 0.17$ \\
\hline & q & $2.31 \pm 0.09$ & $1.22 \pm 0.07$ & $1.11 \pm 0.08$ & $2.81 \pm 0.11$ & $1.54 \pm 0.08$ & $1.18 \pm 0.10$ \\
\hline \multirow{2}{*}{$\begin{array}{l}\text { Total } \\
\text { immatures }\end{array}$} & $\hat{\sigma}$ & $6.25 \pm 0.17$ & $3.10 \pm 0.10$ & $3.38 \pm 0.24$ & $7.72 \pm 0.29$ & $3.51 \pm 0.20$ & $4.01 \pm 0.29$ \\
\hline & $q$ & $6.88 \pm 0.19$ & $3.31 \pm 0.16$ & $3.66 \pm 0.14$ & $8.12 \pm 0.18$ & $3.66 \pm 0.16$ & $4.07 \pm 0.14$ \\
\hline \multirow{2}{*}{ Life cycle } & $\hat{0}$ & $9.58 \pm 0.20$ & $4.90 \pm 0.19$ & $5.51 \pm 0.20$ & $11.29 \pm 0.24$ & $5.14 \pm 0.31$ & $6.01 \pm 0.50$ \\
\hline & $q$ & $10.31 \pm 0.25$ & $5.16 \pm 0.19$ & $5.69 \pm 0.16$ & $11.95 \pm 0.18$ & $5.76 \pm 0.19$ & $6.28 \pm 0.16$ \\
\hline \multirow{2}{*}{$\begin{array}{l}\text { Adult } \\
\text { longevity }\end{array}$} & $\hat{\sigma}$ & $4.92 \pm 0.33$ & $15.80 \pm 1.36$ & $14.25 \pm 1.55$ & $4.83 \pm 0.21$ & $16.50 \pm 2.10$ & $17.33 \pm 1.20$ \\
\hline & $q$ & $7.63 \pm 0.37$ & $24.33 \pm 0.93$ & $23.09 \pm 0.71$ & $8.33 \pm 0.21$ & $25.35 \pm 0.77$ & $25.69 \pm 0.75$ \\
\hline \multirow{2}{*}{ Life span } & $\hat{0}$ & $14.50 \pm 0.32$ & $20.70 \pm 1.49$ & $19.76 \pm 1.74$ & $16.12 \pm 0.35$ & $21.64 \pm 2.03$ & $23.34 \pm 1.69$ \\
\hline & q & $17.94 \pm 0.49$ & $29.49 \pm 0.95$ & $28.78 \pm 0.70$ & $20.28 \pm 0.26$ & $31.11 \pm 0.79$ & $31.97 \pm 0.79$ \\
\hline
\end{tabular}

The intrinsic rate of natural increase $\left(\mathrm{r}_{\mathrm{m}}\right)$ of T. urticae was 0.255 and 0.188 female/female /day when reared on Aswan and Giza-1 cultivars at $30^{\circ} \mathrm{C}$, respectively; while it was 0.188 and 0.139 female/ female/day at $25^{\circ} \mathrm{C}$, respectively. The shortest mean generation time (T) of P. persimilis was 12.40 days on Aswan cultivar at $30^{\circ} \mathrm{C}$; while the longest was 16.41 days on Giza-1 cultivar at $25^{\circ} \mathrm{C}$.Its highest intrinsic rate of natural increase $\left(r_{m}\right)$ was 0.285 female/female /day on Aswan cultivar at $30^{\circ} \mathrm{C}$; while the lowest was 0.217 female/female /day on Giza-1 cultivar at $25^{\circ} \mathrm{C}$.

The net reproductive rate $\left(\mathrm{R}_{\mathrm{o}}\right)$ of $P$. persimilis was 34.27 and 35.12 female/female /day on Aswan and Giza-1 cultivars at $30^{\circ} \mathrm{C}$, respectively; while it was 36.31 and 35.26 female/female /day at $25^{\circ} \mathrm{C}$, respectively. The intrinsic rate of natural increase mean generation time $(\mathrm{T})$ and net reproductive rate $\left(\mathrm{R}_{\mathrm{o}}\right)$ of $N$. californicus showed similar trend as $P$. persimilis (Table 4). 


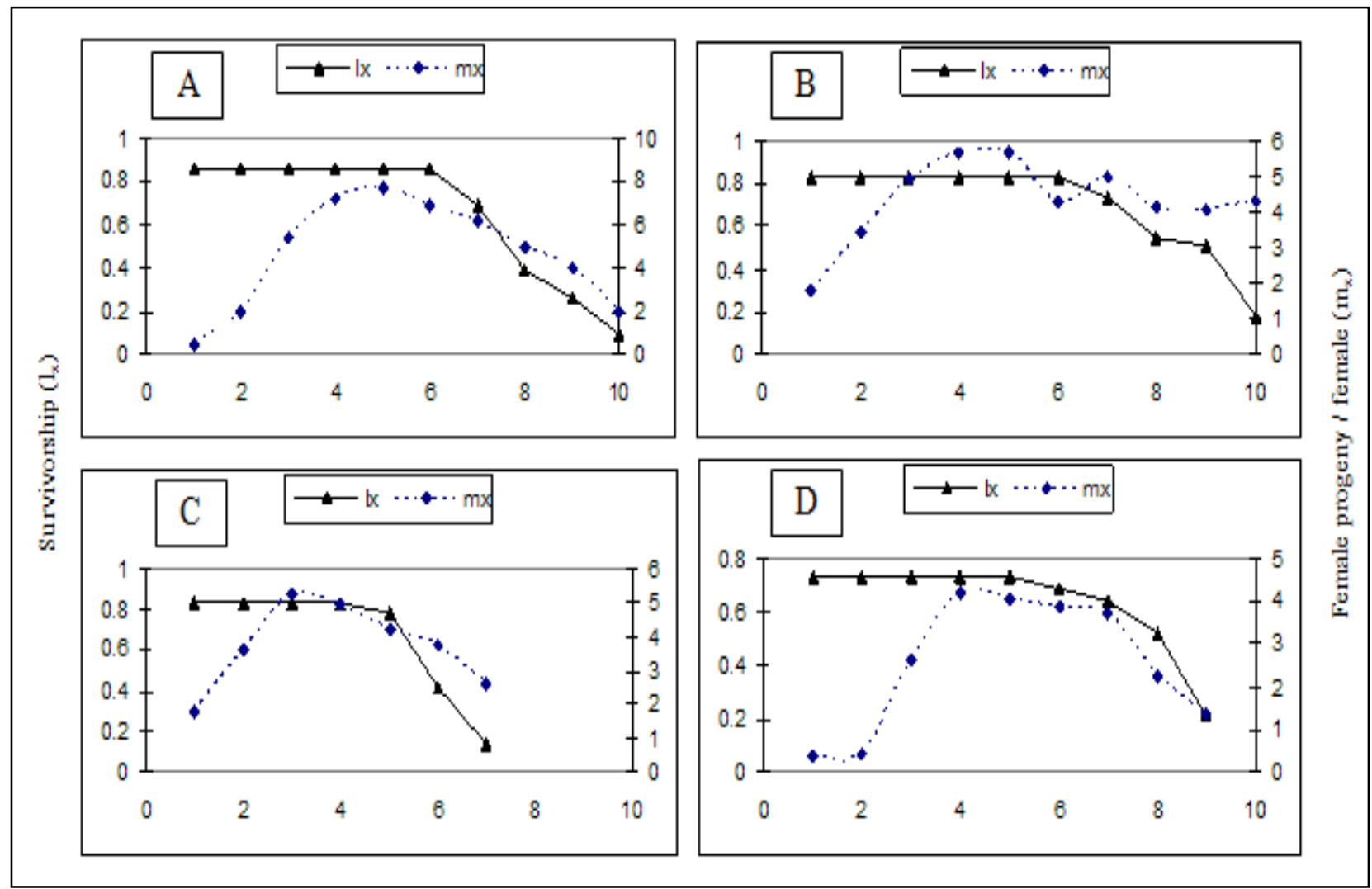

Fig. (1). Age-specific survivorship $\left(1_{\mathrm{x}}\right)$ and age-specific birth rate $\left(\mathrm{m}_{\mathrm{x}}\right)$ of $T$. urticae reared on leaves of two watermelon cultivars at two different temperatures. $\mathrm{A} \& \mathrm{~B}=\mathrm{Aswan}$ cultivar at $30 \& 25^{\circ} \mathrm{C}$, and $\mathrm{C} \& \mathrm{D}=\mathrm{Giza}-$ 1 cultivar at $30 \& 25^{\circ} \mathrm{C}$.
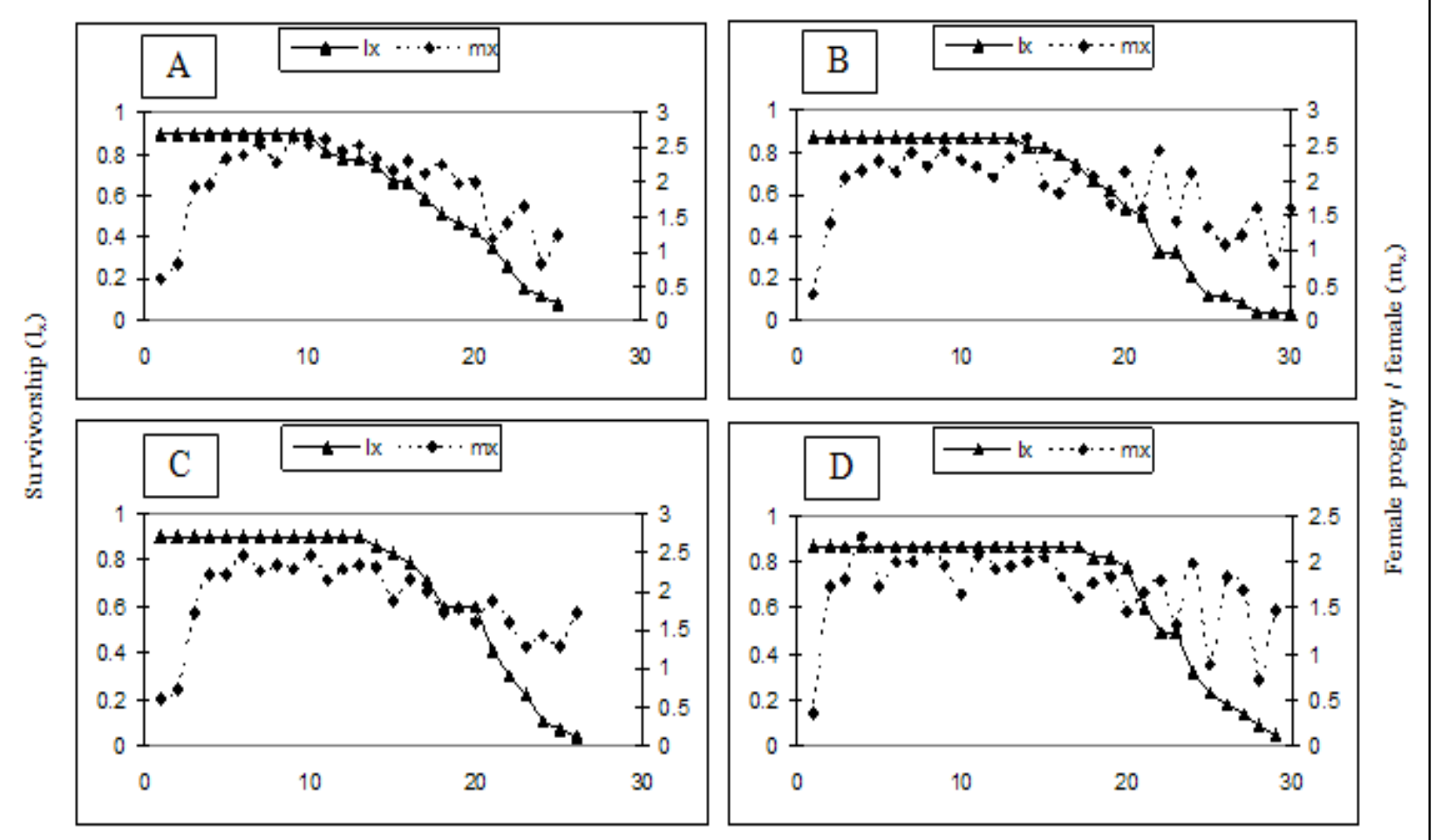

Fig. (2). Age-specific survivorship $\left(1_{\mathrm{x}}\right)$ and age-specific birth rate $\left(\mathrm{m}_{\mathrm{x}}\right)$ of P. persimilis fed on T. urticae at leaves of two watermelon cultivars and two different temperatures. $A \& B=A s w a n$ cultivar at $30 \& 25{ }^{\circ} \mathrm{C}$ and $\mathrm{C} \& \mathrm{D}=$ Giza- 1 cultivar at $30 \& 25^{\circ} \mathrm{C}$. 


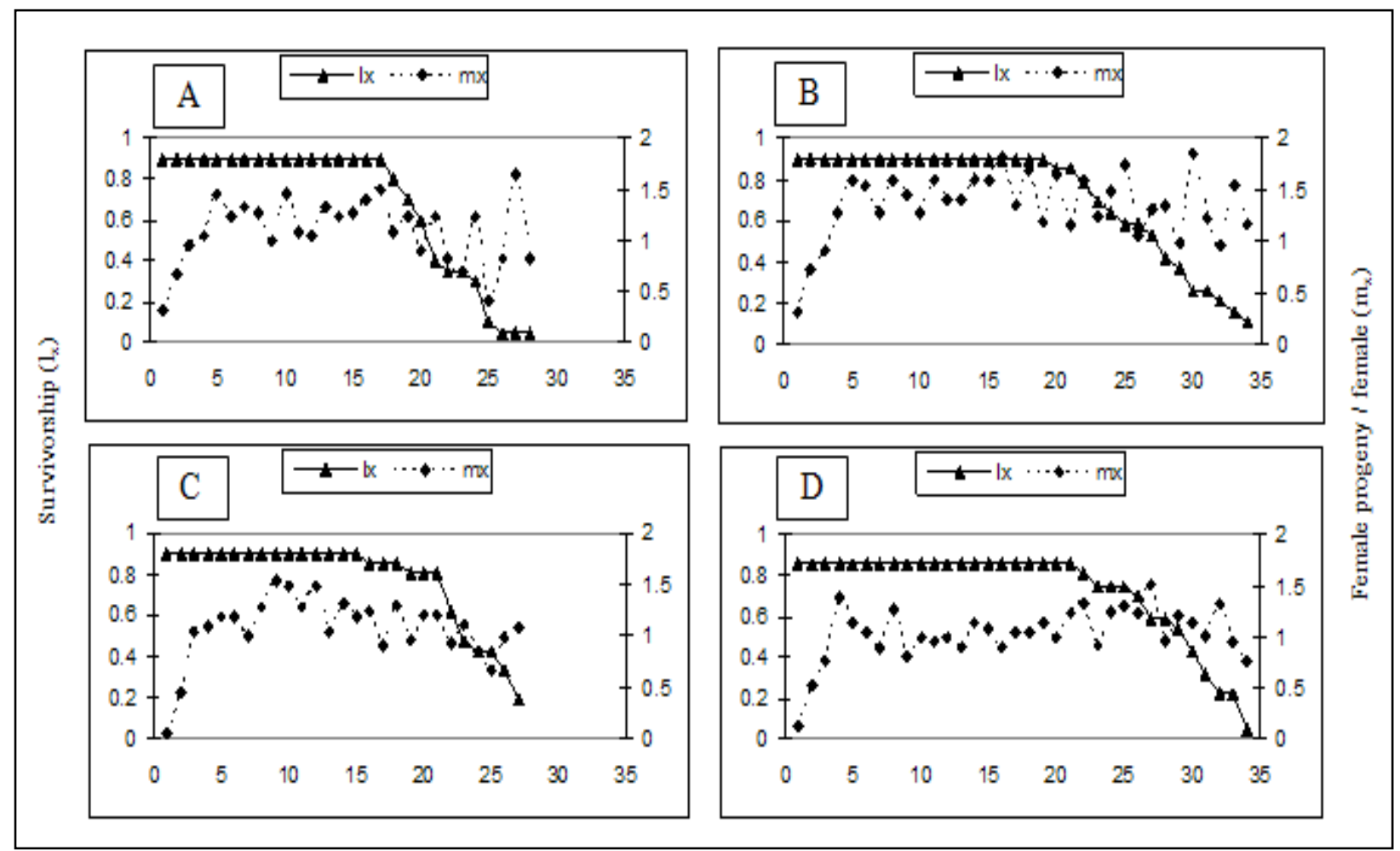

Fig. (3). Age-specific survivorship $\left(1_{\mathrm{x}}\right)$ and age-specific birth rate $\left(\mathrm{m}_{\mathrm{x}}\right)$ of $N$. californicus fed on T. urticae at leaves of two watermelon cultivars and two different temperatures. $\mathrm{A} \& \mathrm{~B}=$ Aswan cultivar at $30 \& 25{ }^{\circ} \mathrm{C}$ and $\mathrm{C} \& \mathrm{D}=$ Giza- 1 cultivar at $30 \& 25^{\circ} \mathrm{C}$.

Table (4). Effect of two watermelon cultivars and two temperatures on the life table parameters of Tetranychus urticae, Phytoseiulus persimilis and Neoseiulus californicus.

\begin{tabular}{|c|c|c|c|c|c|c|c|}
\hline \multirow{2}{*}{$\begin{array}{c}\text { Mite } \\
\text { species }\end{array}$} & \multirow{2}{*}{$\begin{array}{c}\text { Watermelon } \\
\text { cultivars }\end{array}$} & \multirow{2}{*}{ Temp. } & \multicolumn{5}{|c|}{ parameters } \\
\hline & & & $(T)$ & $\left(R_{o}\right)$ & $\left(r_{m}\right)$ & $(\lambda)$ & Sex ratio (female/total) \\
\hline \multirow{4}{*}{ T.urticae } & \multirow{2}{*}{ Aswan } & $25 \pm 19 \mathrm{C}$ & 18.10 & 30.28 & 0.188 & 1.21 & 72.00 \\
\hline & & $30 \pm 1 ㅇ$ & 13.68 & 32.81 & 0.255 & 1.29 & 77.80 \\
\hline & \multirow{2}{*}{ Giza-1 } & $25 \pm 1 ㅇ$ & 19.52 & 15.04 & 0.139 & 1.15 & 77.00 \\
\hline & & $30 \pm 1 \mathrm{C}$ & 15.40 & 18.16 & 0.188 & 1.21 & 72.00 \\
\hline \multirow{4}{*}{ P. persimilis } & \multirow{2}{*}{ Aswan } & $25 \pm 19 \mathrm{C}$ & 15.05 & 36.31 & 0.239 & 1.27 & 81.00 \\
\hline & & $30 \pm 1 \div \mathrm{C}$ & 12.40 & 34.27 & 0.285 & 1.33 & 82.00 \\
\hline & \multirow{2}{*}{ Giza-1 } & $25 \pm 1 \div \mathrm{C}$ & 16.41 & 35.26 & 0.217 & 1.24 & 73.00 \\
\hline & & $30 \pm 1 \div \mathrm{C}$ & 13.20 & 35.12 & 0.270 & 1.31 & 86.00 \\
\hline \multirow{4}{*}{ N. californicus } & \multirow{2}{*}{ Aswan } & $25 \pm 1$ 으 & 15.85 & 33.02 & 0.221 & 1.25 & 77.00 \\
\hline & & $30 \pm 1$ 으 & 12.72 & 21.53 & 0.241 & 1.27 & 82.00 \\
\hline & \multirow{2}{*}{ Giza-1 } & $25 \pm 1 ㅇ$ & 18.59 & 25.57 & 0.174 & 1.19 & 76.00 \\
\hline & & $30 \pm 1$ 으 & 14.82 & 22.85 & 0.211 & 1.24 & 86.00 \\
\hline
\end{tabular}

$(T)=$ Generation time in days, $\quad\left(\mathrm{R}_{\mathrm{o}}\right)=$ Net reproductive rate, $\quad\left(\mathrm{r}_{\mathrm{m}}\right)=$ Intrinsic rate of natural increase per day and $(\lambda)=$ Finite rate of increase per day.

Statistical analysis of the obtained results revealed the occurrence of significant differences of developmental duration periods between rearing on leaves of Aswan and Giza-1 cultivars. Watermelon cultivars and temperatures also, greatly affected $T$. urticae, $P$. persimilis and $N$. californicus fecundity and life table parameters. These were in agreement with (Castagnoli and Simoni, 1991; Ali, 1998;
Bonato, 1999; Canlas et al., 2006; Kazak and Kibritçi, 2008 and Razmjou et al., 2009).

In the present study, in addition to the difference between the intrinsic rates of natural increase $\left(r_{m}\right)$ of T. urticae fed on two watermelon cultivars, there were significant differences between the total developmental times, the longevity and reproductive 
potentials on two watermelon cultivars. The $r_{m}$ value is an important parameter, describing the growth potential of a population under climatic and food conditions, as it reflects the overall effects of temperature and food on development, reproduction and survival characteristic of the populations (Southwood, 1978).

These variations determined on two different watermelon cultivars might be due to leaf chemical contents, and its texture. These leaf characteristics significantly affected oviposition and developmental rates of $T$. urticae and playing an important role in the direct.

It can be concluded that no single factor is responsible in mite population fluctuation but the all factors work in compliment with each other. The morphological plant characters are also very important in affecting the movements of the predatory mites during the search of its prey within the plant canopy. Therefore, it is suggested that relationship of morphological plant characters with predator should also be considered before using in biological control programme.

\section{REFERENCES}

Abou-Setta, M. M.; Sorrell, R.W. and Childers, C. C. 1986. Life-48, a BASIC computer program to calculate life table parameters for an insect or mite species. Fla. Entomol., 69 (4): 690: 697.

Ali, F. S. 1998. Life tables of Phytoseiulus macropilis (Banks) (Gamasida: Phytoseiidae) at different temperatures. J. Exp. \& Applied Acarology, 22: 335-342.

Bengston, M. 1970. Effect of different varieties of the apple host on the development of Tetranychus urticae (Koch). Queensland Journal of Agricultural and Animal Sciences, 27: 95-114.

Birch, L.C. 1948. The intrinsic rate of natural increase of an insect population. J. Arum. Ecol., 17: 15-26.

Bonato, O. 1999. The effect of temperature on life history parameters of Tetranychus evansi (Acari:Tetranychidae). J. Exp. \& Applied Acarology, 23: 11-19.

Canlas, L. J.; Amano, H.; Ochiai, N. and Takeda, M. 2006. Biology and predation of the Japanese strain of Neoseiulus californicus (McGregor) (Acari: Phytoseiidae). J. Systematic \& Applied
Acarology, 11:141-157.

Castagoli, M. and Simoni, S. 1991. Influence of temperature on the population growth of Amblyseius californiciis (McGregor) (Acari: Phytoseiidae). Redia, 74(2): 621-640.

Crooker, A., 1985. "Embryonic and juvenile development". In: Spider Mites. Their Biology, Natural Enemies and Control (Eds. Helle, W. \& Sabelis, M. W.), Elsevier, Amsterdam, World Crop Pests, 1: 149-163.

El-Saiedy, E. M. A.; Afifi, A. M.; Ali, F. S. and Ahmed, M. M. 2011. Susceptibility of four watermelon cultivars to infestation with Tetranychus urticae Koch. Acarines, $5: 23-28$.

Kazak, C. and Kibritçi, C. 2008. Population parameters of Tetranychus cinnabarinus Boisduval ((Prostigmata :Tetranychidae) on eight strawberry cultivars. Turk. J. Agric., 32:19-27.

Laing, J. E. 1969. Life history and life table of Tetranychus urticae Koch. Acarologia, 11(1): 32-42.

Razmjou, J.; Vorburger, C.; Tavakkoli, H. and Fallahi, A. 2009. Comparative population growth parameters of the two-spotted spider mite, Tetranychus urticae Koch (Acari: Tetranychidae), on different common bean cultivars. J. Systematic and Applied Acarology, 14 (2): 83-90.

Sabelis, M. W. 1985. Reproductive strategies. In: Spider Mites. Their Biology, Natural Enemies and Control. World Crop Pests, (Eds.: Helle, W. and Sabelis, M.W.), Elsevier, Amsterdam, 1A: 265-278.

Southwood, T. R. E. 1978. Ecological Methods. Chapman and Hall, New York, 524pp.

Tomczyk, A. and Kropczynska, D. 1986. "Effects on the host plant, 149-163". In: Spider Mites. Their Biology, Natural Enemies and Control (Eds. Helle, W. \& Sabelis, M. W.), Elsevier, Amsterdam, World Crop Pests. 1A, 405pp.

Vrie, M.; van de, J.; McMurtry, A. and Huffaker, C. B. 1972. Ecology of tetranychid mites and their natural enemies: a review. III. biology, ecology and pest status and host plant relations of tetranychids. Hilgardia, 41: 343-432.

Zhang, Z. J.;Wu, Q. J.; Li, X. F.; Zhang, Y. J.; Xu, B.Y. and Zhu, G. R. 2007. Life history of western flower thrips, Franklinville occidentalis (Thysan., Thripidae), on five different vegetable leaves. J. Appl. Entomol., 131: 347-354. 